\title{
URGENCY TOWARDS ECONOMIC DIVERSIFICATION THROUGH EFFECTIVE REFORMS IN CASPIAN BASIN
}

\author{
Tahira Yasmin \\ Al Ain University, Al Ain, UAE \\ Ghaleb A. El Refae \\ Al Ain University, Al Ain, UAE \\ Shorouq Eletter \\ Al Ain University, Al Ain, UAE
}

\begin{abstract}
This paper highlights that, in the Caspian Basin, the COVID-19 pandemic and oil price fluctuations have cast negative impacts on oil-exporting economies. These resource-abundant economies have faced revenue contraction and dwindling budget expenditures due to oil price changes. This study has examined export and economic diversification analyses for all economies and has concluded that the Caspian region cannot achieve full economic diversification due to over-dependence on oil revenues. Most of the export-oriented sectors consist of minerals and oil and gas, neglecting the more sustainable growth of non-resource tradable sectors. As a result, the export diversification index demonstrates that a huge share of exports in these countries is mainly natural resources. Economic diversification, which is based on sectoral value-added, also indicates that these countries show some signs of diversity, but the utmost need to have structural reforms and policy instruments to diversify their revenue stream remains. However, with the passage of time and a renewable energy strategy, these economies will achieve economic diversification targets.
\end{abstract}

Keywords: Revenue Contraction, COVID-19, export diversification, economic diversification, oil resources, renewable energy.

DOI: http://dx.doi.org/10.15549/jeecar.v7i3.326

\section{INTRODUCTION}

The oil market has gone through significant changes and transitions since 2014, but the last quarter of 2018 was quite tough. Oil supply shocks engulfing the market included the loss of supply from Iran, U.S. sanctions on Venezuela, and the fragility of resources from other sources of OPEC production such as Libya and Nigeria. 
The imposition of international oil sanctions also negatively impacted reliable access to oil, leading to further economic challenges. Moreover, the global oil market is unbalanced because it does not operate purely on demand and supply forces because there often is uncertainty in the oil market due to escalations of tensions. Oil geopolitics, therefore, plays a central role and disrupts the natural flow of crude oil and makes oil a source of power (Christie, 2016; Noguera, 2016; Chen, Fu, Zhao, Yuan \& Chang, 2019; Högselius \& Kaijser, 2019).

A recent example of severe oil market price volatility occurred amid the COVID-19 pandemic when, on March 08, 2020, Russia cancelled its alliance with OPEC + and decided to increase its oil supply. Saudi Arabia escalated the situation by increasing oil output, resulting in historical oil price volatility. But due to less global oil demand, this oversupply mechanism could not work for long as a suitable strategy. It is estimated that the slowdown in economic activities, air travel restrictions and a global lockdown - all due to COVID-19 - has resulted in the lowest oil demand in decades. As a result, oil-producing economies started to discuss possible vital solutions to control oil prices. On 9 April, 2020, Saudi Arabia and Russia ended their oil price war by agreeing to slash oil output together to revive the global oil market. The OPEC+ group agreed to cut output by an initial $9.7 \mathrm{mb} / \mathrm{d}$ effective on May 1, 2020. Furthermore, in light of the COVID-19 crisis, major oil consumers and producers were urged to work together to mitigate the impact on market stability (IEA, 2020).

Because they were specifically extractive economies, the oil and gas rich states of the Caspian Basin have had significant growth in the 2000s. But over time, the sanctions on Russia in 2014, the triumvirate of shocks, declining trade and remittance networks and changes in global energy demand combined to weaken these economies. These economies face an ongoing challenge to move away from commodity-based growth strategies toward market-oriented diversification and they have gone through various negotiations and government reforms to ease tensions, but diversification goals have not been fulfilled. Still, though, the advocates of economic reforms have hope that the many restructuring efforts and a broader reforms agenda will move these economies beyond resource dependency (Zabortseva, 2012; O'Neill, 2014; Bayramov, 2019; Zakharov, 2020).

Due to various challenging aspects in the Caspian Basin, the underlining fact is that, diversification away from oil is needed to enhance GDP per capita and achieve long-term sustainable economic growth. A period of low oil prices has also convinced policymakers in Caspian Basin economies that there is a need for diversification and structural reforms to save the economies from external shocks. Djimeu and Omgba (2019) examined the factors behind export diversification in oil export economies. They found that an oil boom negatively affects export diversification only if the countries initially exhibit low diversification levels. But in contrast, in the countries with a high level of diversification before an oil boom, the oil boom has no impact on diversification, indicating the close interaction oil has with economic activities when it is a major production source.

Based on the factors mentioned above, a study of this resource-rich region during the COVID19 crisis time concerning oil market challenges should be interesting. The paper is organized as follows: the next section is a literature review; the section after that measures both export and economic diversification; the stylized facts of oil and diversification in these countries then are assessed; and, lastly, concluding remarks.

\section{LITERATURE REVIEW}

This section summarizes the various literature on economic diversification and regional challenges in the Caspian Basin, especially related to oil and gas. Ciarreta and Nasirov (2012) discussed how the main issues, such as the lack of independent regulatory institutions, rehabilitation of oil refineries, and the resolution of the Caspian Sea's legal status, remain major challenges for further development of the oil and gas industries. Moreover, Alsharif, Bhattacharyya, and Intartaglia (2017) revisited the literature regarding oil-exporting economies and the diversification process and suggested that countries should enhance the non-oil sector performance in order to diversify successfully. They mentioned that the three economies of 
Azerbaijan, Kazakhstan, and Russia have a heavy reliance on the value chain of raw materials as compared to high value goods. In a critical review of the natural resource curse, Badeeb, Lean, and Clark (2017) suggested that oil resource economies should seek efficient macroeconomics management to enhance overall economic growth.

Hasanov (2013) tested the "Dutch Disease" hypothesis in the Azerbaijan economy and revealed that foreign direct investment inflows to the oil sector are harmful for non-oil exports and contribute to oil dependence. The findings suggested that there should be balanced long term economic growth with the development of the non-oil sector. In another study, Hasanov and Huseynov (2013) mentioned that financial sector development policies could drive Azerbaijan economic growth, especially in nonoil sectors. This point was reinforced by Aslanli (2015), who mentioned that the State Oil Fund of the Azerbaijan Republic (SOFAZ) had become a leading part of the financing channel. This proved to be an effective measure in resource revenue management to achieve economic growth. Recently, Gritsenko and Efimova (2020) pointed out that some resource-based Russian Arctic regions are not immune to economic problems and suggested that sustainable planning can lead to better economic performance by enhancing resource development.

Gerelmaa and Kotani (2016) concluded a surprising fact that natural resource rich countries faced resource curse problems from 1970 to 1990 , but with the later economic development and manufacturing process there is no impact of this curse. So, if a country is able to diversify its economy and have a developed manufacturing sector, it can easily escape from being too dependent on natural resources. Various aspects of over-dependence on natural resources and challenges in economic diversification have been highlighted by researchers. Bayramov and Abbas (2017) mentioned that the oil price shock in 2014, resulted in an economic slowdown in the oil exporting countries of the Caspian region, namely Russia, Kazakhstan and Azerbaijan. Moreover, they concluded that high oil dependence cast a negative effect on other non- oil sectors and resulted in poor government finance and diversification plans.

Moreover, some researchers have discussed the economic development and structural transformation process in the Russian economy by considering some cyclical factors (see Mau, 2017; Medvedev, 2017; Bradshaw, de Graaf, and Connolly, 2019), and Lee (2014) pointed out that Turkmenistan's diversification policies had various risks and opportunities at the same time. There is a need for careful planning in each context when a country decided to diversify. Aitzhanova, Iskaliyeva, Krishnaswamy, Makauskas, Razavi, Sartip, and Urazaliyeva (2015) discussed that in the case of Kazakhstan, it is important to plan to be a non-oil economy in a time of peak oil production. Moreover, oil funds should be transferred on a transparent basis. They conducted some scenario analysis which could help the country to achieve balanced sectoral growth. Malova and van der Ploeg (2017) mentioned that any depletion of these resources would tighten the fiscal situation despite oil and gas resources in Russia. Hafezi, Malekifar, and Akhavan (2018) reviewed Iran's historical energy strategies by developing some scenario analysis. They recommended win-win interactions in the international market to resolve the energy issue with dynamic strategies. Li, Semeyutin, Lau, and Gozgor (2019) evaluated the oil price vitality effect on credit default swaps for the Kazak economy. They concluded that Kazakhstan is more sensitive to the global "fear index barometer" of index and oil price volatility. The findings might be appealing for portfolio diversification strategies because Kazakhstan's credit default swaps are in the low oil dependency regime.

Based on the previous studies, various researchers have highlighted the mechanism of diversification, investment, and resource policies in Caspian economies. However, this current study revises the measures of export diversification, concentration, and economic diversification aspects. It has another added value that, due to the critical health crisis, it is time to shed light on these issues and document some facts that will be effective for future decision making. 


\section{MEASURING DIVERSIFICATION}

To measure this index, we have used annual data from the United Nations Conference on Trade and Development (UNCTAD) for each country from 2007 to 2018. First, the diversification index is measured by computing the absolute deviation of a country's trade structure compared to the world. This index is calculated based on Equation 1 as below:

$$
S_{j}=\frac{\sum_{i}\left|h_{i j}-h_{i}\right|}{2}
$$

where hij is the share of product $\mathrm{i}$ in total exports or imports of a country or group of countries $j$. while hi is the share of product $i$ in the total world exports or imports. This index also lies between 0 and 1, where a value closer to 1 depicts a greater divergence from the world pattern (Finger \& Kreinin, 1979).

In resource-rich countries, diversification may be affected due to endowments of natural resources with abundant land over the capital, as it is easier for them to specialize in natural resource-intensive exports. Figure 2 shows that all three resource-rich economies are highly dependent on fuel and mineral exports, as can be seen by the value of this index is poised around 0.6-0.7 in most of the Caspian economies during the study time frame. In particular, Azerbaijan demonstrated the highest reliance on minerals, as its $\mathrm{Sj}$ index exceeds 0.8 , especially during the 2009 Global Financial Crisis. This implies that there is an entire need for diversification of exports in various sectors. The current COVID-19 pandemic impact is still uncertain but could have global spillover effects that will derail these economies in the next economic outlook. Barro, Ursua, and Weng (2020) highlighted a vital point that this pandemic's magnitude is unclear but surely will have a devastating impact, just as previous epidemics have had on economic activities. On the other hand, the Azerbaijan and Russian economies face more travails as the crude oil price fell below zero because of limited liquidity and limited storage (EIA, 2020).

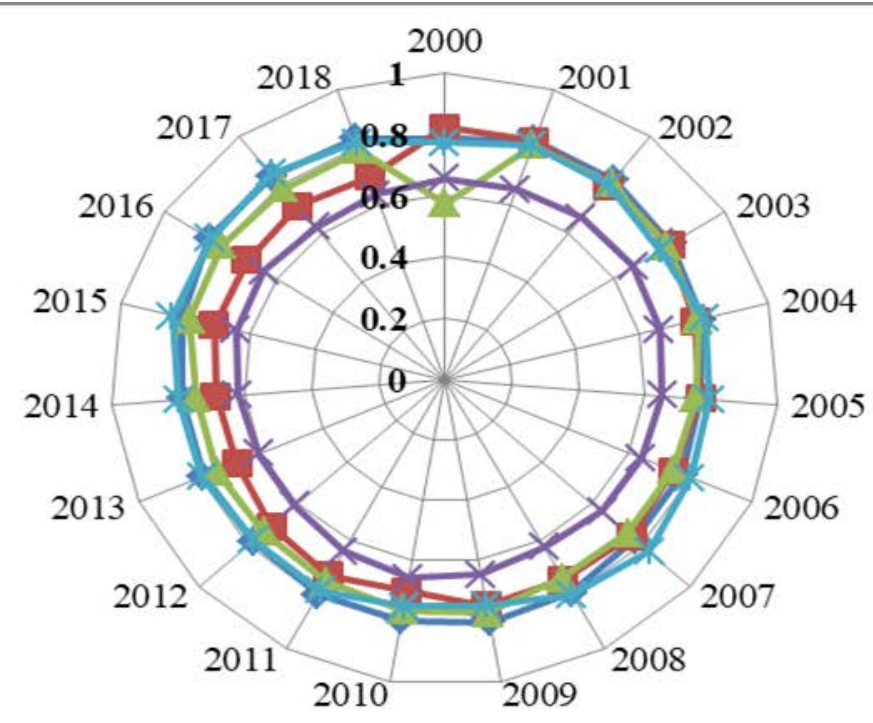

\section{Export Diversification Index}

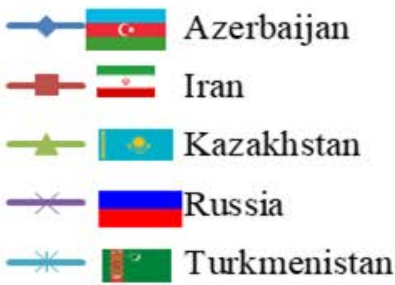

Figure 2: Caspian Basin Export Diversification Index.

Source: UNCTAD (2020).

Second, the concentration indicator, also defined as the Herfindahl-Hirschmann Index (Product HHI), is a measure to capture the degree of product concentration. The value usually lies between 0 and 1 and shows the product concentration of exports at the product level and is calculated by using Equation 2 as below: 


$$
H_{j}=\frac{\sqrt{\sum_{i=1}^{N}\left(\frac{X_{i j}}{X_{j}}\right)^{2}}-\sqrt{\frac{1}{N}}}{1-\sqrt{\frac{1}{N}}}
$$

where $\mathrm{Hj}$ displays the product concentration index of exports for country $\mathrm{j}$, Xij is the value of exports of product $\mathrm{i}$ by country $\mathrm{j}, \mathrm{Xj}$ is the total value of exports of country $\mathrm{j}$ and $\mathrm{N}$ implies the total number of products exported at the threedigit level of the SITC, Revision 3. Overall, the concentration index of exports ranges from zero to one; the higher the value of the concentration index the higher the concentration of exports. Chandra, Boccardo and Osorio (2007) mentioned that usually $\mathrm{HHI}$ is lower than 0.05 in advanced economies due to a high diversified export pattern, whereas a value higher than 0.4 depicts a higher concentration in this regard.

Figure 3 summarizes the export concentration index in Caspian region economies by displaying the various indices. Each economy depicts different characteristics in the concentration of exports, but the lowest value appears mainly in Russia. This might be too low, however, because this index includes all the products that comprise exports. For Azerbaijan and Kazakhstan, the prominent number of product concentration is due to the significantly increased share of petroleum in their export baskets. The important point to highlight here is that all three resource-rich countries have the largest share of mineral fuels, lubricants, and related materials in exports. In this regard, Hendrix (2019) highlighted that this indicates a need to diversify from oil and gas resources, otherwise with an economic boom and bust scenario, a resource-dependent economy will suffer. These indicators primarily highlight the challenge when there are fewer non-oil exports, and most revenues are generated by natural resources. This phenomenon leads to unbalanced economic growth and natural resource sector segmentation.
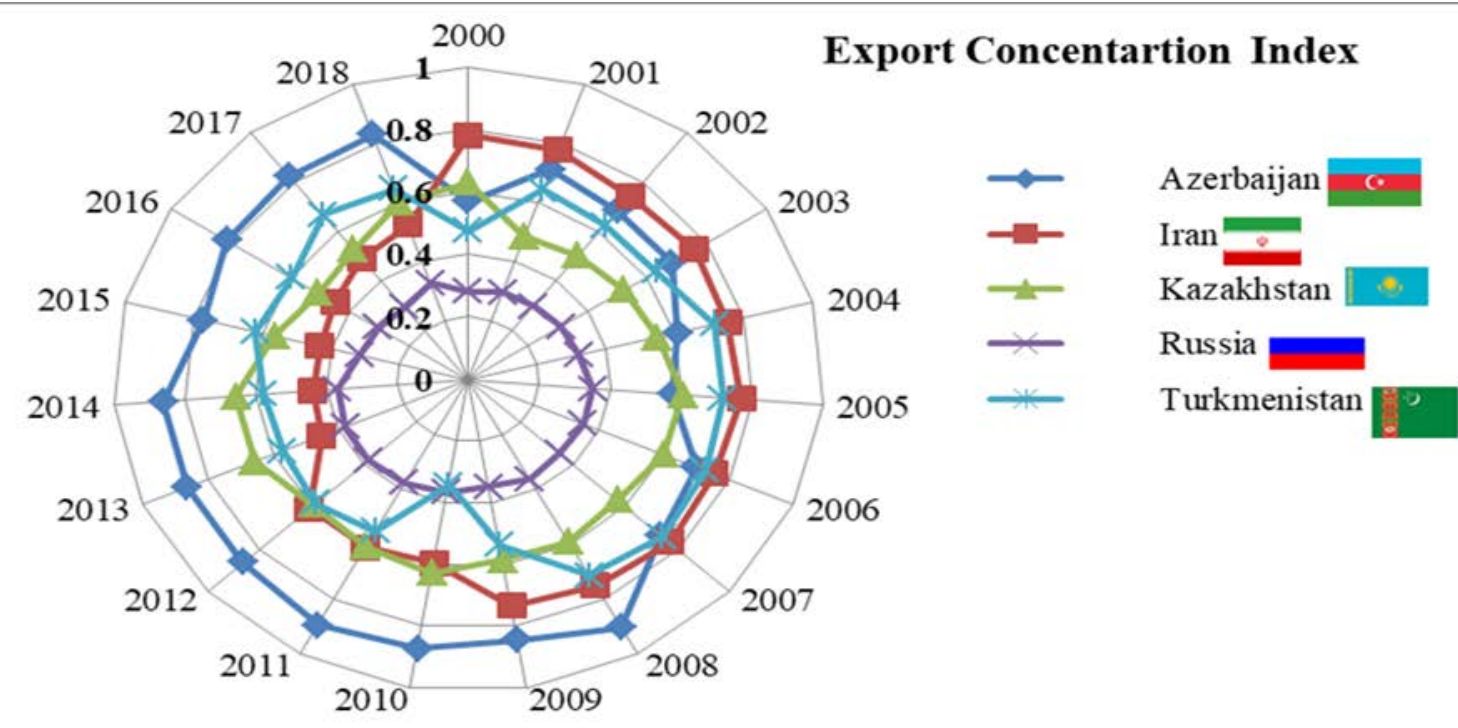

Figure 3: Caspian Basin Export Concentration Index.

Source: UNCTAD (2020).

\section{Economic Diversification}

To measure the extent of economic diversification in Caspian Basin countries, United Nations Statistics Division (2020) data on the International Standard Industrial Classifications (ISIC) is used. Based on this ISIC dataset, various categories, such as A and B, stand for agriculture, hunting, forestry and fishing, $C$ and $E$ for mining and utilities, D for manufacturing, $\mathrm{F}$ for construction, $\mathrm{G}$ and $\mathrm{H}$ for wholesale, retail trade, restaurants and hotels, I for transport, storage and communication. The 
formula for economic diversification is constructed in Equation 3 below:

$$
H H I=\left(\frac{A+B}{100}\right)^{2}+\left(\frac{C+E}{100}\right)^{2}+\left(\frac{D}{100}\right)^{2}+\left(\frac{F}{100}\right)^{2}+\left(\frac{G+H}{100}\right)^{2}+\left(\frac{I}{100}\right)^{2}
$$

Overall, in terms of economic diversification, Russia and Kazakhstan perform better as compared to export indices. The export structure depicts the highest dependence on minerals and oil, but the value-added as share in GDP shows a relatively balanced structure of the economy. This is evidence that the manufacturing sector has increased its share in GDP, and it also can be seen in the movement of the concentration ratios in both countries. In Azerbaijan, the result is disappointing, as the mining and manufacturing sector's share in GDP is still very high. The value-added balanced by a corresponding increase in other services such as the textile and construction sectors still needs improvement. In the case of Turkmenistan, economic activities show the effect of business regulatory reforms with the privatization of state-owned enterprises. Last, the Iranian economy has some sector's showing a downward trajectory due to U.S. sanctions on oil exports. Bonyani and Alimohammadlou (2018) mentioned that Iran has an opportunity to benefit in the post-sanctions era, as many international firms are interested in its energy sector. Unfortunately, rather than the situation getting better, the COVID-19 pandemic hit, which hit the Iranian economy hard.

Regarding concentration ratios, the top four economic activities are included during 20072018. These ratios move together with HHI, but Kazakhstan experienced some fluctuations during 2011-2013. Overall, Caspian economies have economic concentration ratios, mainly lying around 0.1-0.8 during 2007-2018. Medvedev (2016) discussed that the Russian economy already had various strategies to focus on external and domestic challenges, mentioning that many investors have freedom of investment in the country due to structural reforms and business incentives. Balashova and Serletis (2020) also noted that oil prices validate granger causality with overall economic activities in Russia. However, there is a contradictory situation displayed by Azerbaijan due to high fuel prices, which is showing in high concentration values. After 2015, these indicators change, but there is still a need to have effective policies to achieve economic diversification by having stable value-added among various sectors.

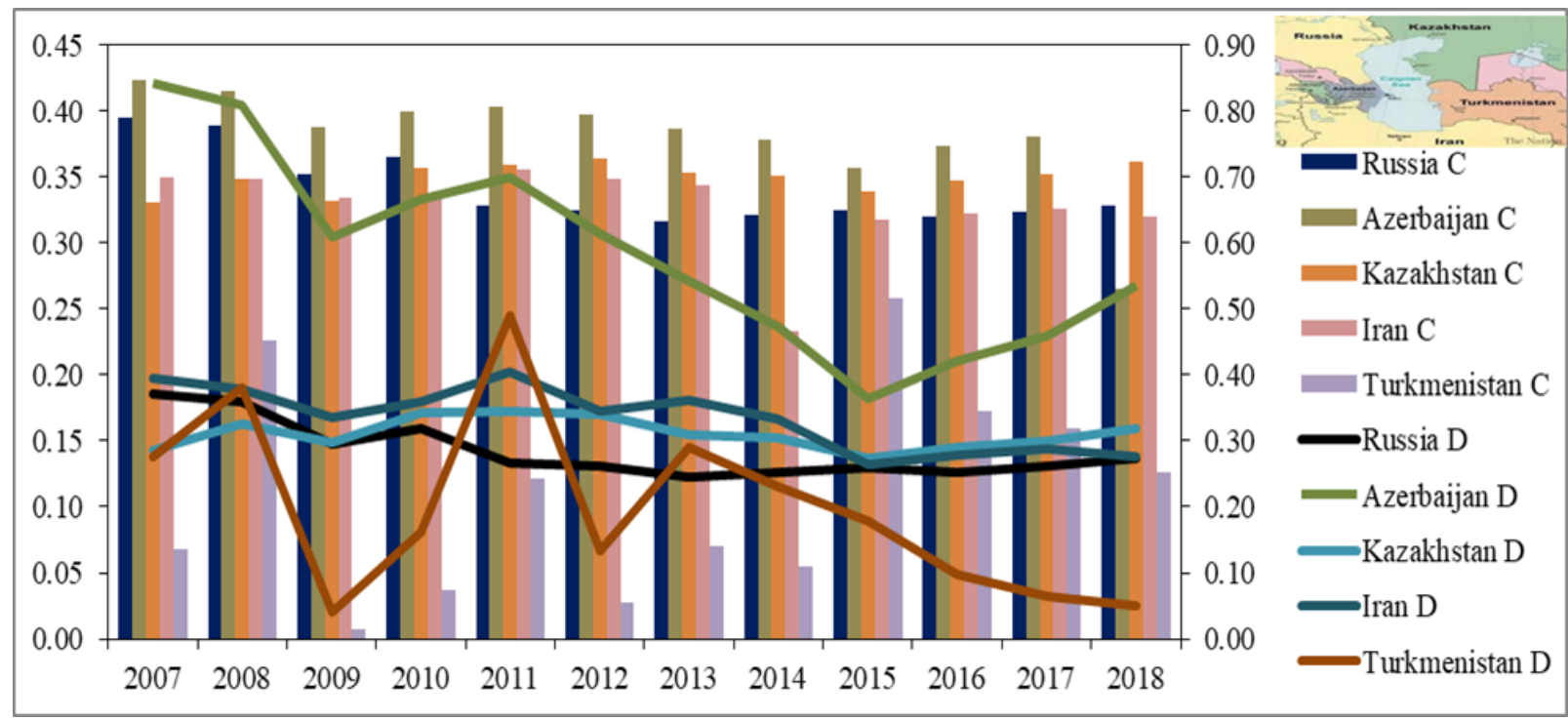

Figure 4: Caspian Basin Economic Diversification and Concentration Index (D stands for diversification on the left axis and $\mathrm{C}$ for concentration on the right axis).

Source: UNCTAD (2020). 


\section{STYLIZED FACTS OF OIL PRICE SHOCK AND THE CASPIAN REGION}

The Caspian Sea is described as the next Alaska or the North Sea for the oil and gas industry; however, the Caspian region is landlocked and is still resolving territorial disputes with respect to complete exploitation of energy resources. This sea should be the "sea of peace and friendship", as it connects Central Asia to Europe and Russia to the Middle East, but the legal disputes increase the complexity of bilateral relations. Unfortunately, the region is building toward a new spiral of geopolitical competition. Various researchers have discussed this geopolitical issue (see Tsantoulis, 2009; Rywkin, 2010; Aburas and Demirbas, 2015; Pleines and Wöstheinrich, 2016; Batsaikhan and Dabrowski, 2017; Bayramov and Abbas, 2017; Dudlák, 2018; Su, Qin, Tao, and Moldovan, 2019).

First considering the Caspian economies, since 2019 the Russian economy has been facing decelerated economic growth of 1.3 percent from 2.5 percent in 2018, and the unemployment rate during 2018 to 2019 increased from 4.6 percent to 4.8 percent, respectively. In the second quarter of 2019, the Russian Federation had modest improvements in export diversification but there was a huge challenge of lower exports receipts in the first and second quarters of 2019 - from US\$ 108.8 to US\$101.7 billion, respectively. This was partly attributed to the contamination of the Druzhba pipeline which affected crude oil exports negatively; export volumes increased later in third quarter of 2019. The vital fact here is that in the Russian economy the oil and gas is the key sector, so any changes in it disrupt the mechanism of all economic activities. Another factor in the first and second quarter of 2019 was the decline of net capital outflows from the private sector by US $\$ 13.4$ billion to US $\$ 0.5$ billion and have decreased substantially further in the third quarter due to geopolitical tensions. FDI also has dropped rapidly from US\$54.5 in 2011-2013 to US\$19.2 billion in 2015-2018. This decline highlighted that $61.5 \%$ of inward FDI was mainly from the minerals and extraction sectors, whereas the outflows also had a huge drop due to limited destinations (World Bank, 2019a).
Second, amid all the ongoing growth, COVID19 and oil price shocks have clouded Azerbaijan's economy. The country felt a direct shock when oil prices plunged to negative in March 2020, and it is projected to have a government budget deficit. The poverty rate already stood at 5.1 percent in 2018 due to an increase in private consumption, but there is fear that the economic upheavals in the first quarter of 2020, which affected trade, tourism, and hospitability, will cause an increase in poverty due to increased unemployment, food price inflation, lower remittances, and deteriorating health conditions. The critical point here is that growth is closely linked with oil, so if oil prices recover in 2021-22, the external balance will improve. But at the same time, there is another scenario that if oil prices remain low as a result of the pandemic, GDP will contract in 2020. Further, this will be accompanied by large imbalances in fiscal and external accounts. In this scenario, poverty will continue, and consumer confidence will deteriorate (World Bank, 2020a).

In the case of Kazakhstan, the challenges are the same as with the above economies due to oil output and a weaker external environment. However, the Kazak government has played a vital role in boosting wages and social transfers to households, which resulted in GDP growth by 4.5 percent in 2019. Meanwhile, the World Bank (2020a) documented that investment rose by 12.9 percent due to FDI investment in the oil and gas industry and residential construction. But there still was a wider account deficit and higher outflows of portfolio investment, causing foreign exchange reserves to fall to $\$ 29$ billion in 2019 from the previous year. The economy turned towards an uncertain situation in midFebruary 2020 when 12-month inflation rose to a 4-6 percent range. Abrupt oil price shocks have put severe strains on the exchange rate 275 bps to 12 percent in March 2020. This economic downfall reflected clearly how the oil market changed as a result of the pandemic.

Turkmenistan, which is one of the five Caspian Sea countries with large volumes of oil and gas, is not a major player in the energy market due to limited export capabilities and infrastructure. EIA (2016) documented that the country has been increasing investment to extend natural 
gas export relations with other countries for the past several years. The country is already leading in the Caspian and Central Asian region in natural gas exports, with more than $70 \%$ of the exports going to China, Russia, and Iran. While there are limited facts and figures regarding COVID-19 impact on the economy, there is an economic impact due to the collapse in energy prices.

Last, Iran's energy sector has had a long redistribution and transformation process, specifically in oil and gas. World Bank (2020b) confirmed that the economy had a contraction in growth in 2019-2020 due to U.S. sanctions, but the effects of the pandemic and declining oil prices have hit the economy hardest. The stringent economic sanctions pose a serious threat to Iran's economic outlook: a 7.6 percent contraction of GDP largely due to a 37 percent decline in the oil sector. Since 2018 oil production has dwindled and reached a low level as of $2 \mathrm{mbpd}$ in December 2019. At the same time, non-oil GDP growth reached close to zero, signaling a broad-based recession. And a long-term pandemic effect could be felt in labor. The government has made cash transfers to 18 million households to compensate, but this initiative cannot fully mitigate the economy's COVID-19 impact.

\section{CONCLUDING REMARKS}

In summary, the current study has concluded that Russia, Azerbaijan and Kazakhstan have a sho high dependence on oil and gas resources. The results suggest that economic diversification for oil and gas exporters does not mean leaving energy behind, however at the same time these economies should understand the pitfalls of over reliance on oil revenues to fuel an entire economy. The oil price shock in 2020 along with the effects of the COVID-19 pandemic have given a new urgency to those economies to diversify their economies. True, the effect of the pandemic has been felt globally, but has it especially hard oil exporting nations. Another important aspect is that political and institutional factors affect diversification within a country, and more effective and capable bureaucratic structures are associated with greater GDP diversification away from oil and gas.
Some collective policy suggestions for all Caspian Basin economies are mentioned in the price of oil and diversification. First is that uncertainty in the oil market with severe price volatility, especially for oil-exporting nations, is an unavoidable factor. Whenever there is any change in the oil market, economic growth in oil-exporting countries moves the same way as the oil market. In the current situation, where COVID-19 has hit the world along with an oil price shock, the impact on oil resource economies has been huge. Although this is not an easy or advisable way to start a new decade, the COVID-19 pandemic and oil price shocks have opened the door to unorthodox intervention in energy markets and global collaboration to support recovery. The huge oil price shock provides an option to introduce long term diversification strategies, forwardthinking, and moving toward a secure energy system to achieve sustainable development growth (Ajami, 2020; Azubike, 2020; Connolly, Hanson \& Bradshaw, 2020).

Second, oil has a political property from the geopolitical point of view. Still, at the same time, the oil market has significant interaction with other economic activities, meaning that energy is both an enabler and disabler of prosperity and economic growth. Due to the collapse in the oil price, expenditures on the import side of the energy sector have significantly dropped so that these economies can reinvest these savings in other energydiversifying projects. Third, this diversification can be in the form of renewable energy projects to avoid any unforeseen situations in the future with respect to oil or gas. There is an opportunity now that, rather than return to the past and depend on oil and gas, countries can look forward and invest in the transition to renewable energy. Then, it can be concluded that there is an urgent need to cut fossil fuel dependence as this has cast a negative impact on the environment and, as we have seen on the economies of countries dependent on the export of fossil fuels. The producer economies should change their economic development models in this regard by opting for long term investment strategies. Last, the stability of the energy market is not what only is required during a shock-like COVID-19. There should be worldwide harmony while working on the same 
energy platform across borders without any geopolitics to combat and face any future catastrophic events.

\section{REFERENCES}

Aburas, H., \& Demirbas, A. (2015). The Caspian Sea Basin, Middle East Petroleum Resources, and the Importance of Turkey. Petroleum Science and Technology, 33(4), 397-405.

Aitzhanova, A., Iskaliyeva, A., Krishnaswamy, V., Makauskas, D., Razavi, H., Sartip, A.Z., \& Urazaliyeva, A. (2015). A practical approach to oil wealth management: Application to the case of Kazakhstan. Energy Economics, 47, 178-188.

Ajami, R. (2020). Globalization, the Challenge of COVID-19 and Oil Price Uncertainty, Journal of Asia-Pacific Business, 21(2), 77-79.

Alieva, L. (2012). Globalization, regionalization and society in the Caspian Sea Basin: overcoming geography restrictions and calamities of oil dependent economies, Southeast European and Black Sea Studies, $12(30,443-453$.

Alsharif, N., Bhattacharyya, S., \& Intartaglia, M. (2017). Economic diversification in resource rich countries: History, state of knowledge and research agenda. Resources Policy. 52, June 154-164.

Aslanli, K. (2015). Fiscal sustainability and the State Oil Fund in Azerbaijan. Journal of Eurasian Studies, 6(2), 114-121.

Azubike, V.C. (2020). Critical government and national oil company role in their petroleum resource development: lessons for Guyana petroleum sector, Commonwealth Law Bulletin, DOI: 10.1080/03050718.2020.1782238

Badeeb, R.A., Lean, H.H., \& Clark, J. (2017). The evolution of the natural resource curse thesis: A critical literature survey. Resource Policy, 51, 123-134.

Balashova, S., \& Serletis, A. (2020). Oil prices shocks and the Russian economy. The Journal of Economic Asymmetries, 21, e00148.

Barro, R.J., Ursua, J.F., \& Weng, J. (2020). The Coronavirus and the Great Influenza Epidemic: Lessons from the 'Spanish Flu' for the Coronavirus's Potential Effects on Mortality and Economic Activity. NBER Working Paper 26866, National Bureau of Economic Research, Cambridge, MA.

Batsaikhan, U., \& Dabrowski, M. (2017). Central Asia - twenty-five years after the breakup of the USSR. Russian Journal of Economics, 3(3), 296-320.

Bayramov, A. (2019). Great game visions and the reality of cooperation around post-Soviet transnational infrastructure projects in the Caspian Sea region. East European Politics, 35(2), 159-181.

Bayramov, V., \& Abbas, G. (2017). Oil shock in the Caspian Basin: Diversification policy and subsidized economies. Resource Policy, 54, 149-156.

Bonyani, A., \& Alimohammadlou, M. (2018). Identifying and prioritizing foreign companies interested in participating in post-sanctions Iranian energy sector. Energy Strategy Reviews, 21, 180-190.

Bradshaw, M., de Graaf, T.V., \& Connolly, R. (2019). Preparing for the new oil order? Saudi Arabia and Russia. Energy Strategy Reviews, 26, 100374.

Chandra, V., Boccardo, J., \& Osorio, I. (2007). Export Diversification and Competitiveness in Developing Countries. World Bank, Washington, D.C.

Chen, Y.E., Fu, Q., Zhao, X., Yuan, X., \& Chang, C. (2019). International sanctions' impact on energy efficiency in target states. Economic Modelling, 82, 21-34.

Christie, H. (2016). The Design and Impact of Western Economic Sanctions against Russia. The RUSI Journal, 161(3), 52-64.

Ciarreta, A., \& Nasirov, S. (2012). Development trends in the Azerbaijan oil and gas sector: Achievements and challenges. Energy Policy, 40, 282-292.

Connolly, R., Hanson, P., Bradshaw, M. (2020). It's déjà vu all over again: COVID-19, the global energy market, and the Russian economy, Eurasian Geography and Economics, DOI: 10.1080/15387216.2020.1776627

Djimeu, E.W. \& Omgba, L.D. (2019). Oil windfalls and export diversification in oil-producing 
countries: Evidence from oil booms. Energy Economics, 78, 494-507.

Dudlák, T. (2018). After the sanctions: Policy challenges in transition to a new political economy of the Iranian oil and gas sectors. Energy Policy, e 121, 464-475.

Energy Information Administration (EIA) (2020). This Week in Petroleum. Retrieved March 13, 2020 from:

https://www.eia.gov/petroleum/weekly/cru de.php

Energy Information Association (EIA) (2016). Turkmenistan. Retrieved April 20, 2020 from: ttps://www.eia.gov/international/analysis/c ountry/TKM

Finger, J.M., \& Kreinin, M.E. (1979). A measure of 'export similarity' and its possible uses. Economic Journal, 89, 905-912.

Gerelmaa, L., \& Kotani, K. (2016). Further investigation of natural resources and economic growth: Do natural resources depress economic growth? Resources Policy, 50, 312-321.

Gritsenko, D., \& Efimova, E. (2020). Is there Arctic resource curse? Evidence from the Russian Arctic regions. Resources Policy, 65, 101547.

Hafezi, R., Akhavan, A.N., \& Pakseresht, S. (2017). Projecting plausible futures for Iranian oil and gas industries: Analyzing of historical strategies. Journal of Natural Gas Science and Engineering, 39, 15-27.

Hafezi, R., Malekifar, S., \& Akhavan, A. (2018). Analyzing Iran's science and technology foresight programs: recommendations for further practices. Foresight, 20(3), 312-331.

Hasanov, F. (2013). Dutch disease and the Azerbaijan economy. Communist and PostCommunist Studies, 46(4), 463-480.

Hasanov, F., \& Huseynov, F. (2013). Bank credits and non-oil economic growth: Evidence from Azerbaijan. International Review of Economics \& Finance, 27, 597-610.

Hendrix, C.S. (2017). Kicking a crude habit: diversifying away from oil and gas in the twenty-first century. International Review of Applied Economics. 33(2), 188-208.
Högselius, P., \& Kaijser, A. (2019). Energy dependence in historical perspective: The geopolitics of smaller nations. Energy Policy, 127, 438-444.

IMF (2016). Russia: Adjusting to Lower Oil Prices, IMF News Report, Retrieved April 13, 2020 from: https://www.imf.org/en/News/Articles/2016 /07/13/13/05/NA071316-Russia-Adjustingto-Lower-Oil-Prices

International Energy Association (IEA) (2020). Oil Market Report, March 2020. Available at: https://www.iea.org/reports/oil-marketreport-april-2020

Lee, Y. (2014). Opportunities and risks in Turkmenistan's quest for diversification of its gas export routes. Energy Policy, 74, 330339.

Li, H., Semeyutin, A., Lau, C.K.M., \& Gozgor, G. (2019). The relationship between oil and financial markets in emerging economies: The significant role of Kazakhstan as the oil exporting country. Finance Research Letters, In Press Corrected Proof, Available at: https://doi.org/10.1016/j.frl.2019.04.028

Malova, A., and van der Ploeg, F. (2017). Consequences of lower oil prices and stranded assets for Russia's sustainable fiscal stance. Energy Policy, 105, 27-40.

Mau, V. (2017). Lessons in stabilization and prospects for growth: Russia's economic policy in 2016. Russian Journal of Economics, 3(2), 109-128.

Medvedev, D. (2017). Social and economic development of Russia: Finding new dynamics. Russian Journal of Economics, 2(4), 327-348.

O'Neill, D.C. (2014). Risky business: The political economy of Chinese investment in Kazakhstan. Journal of Eurasian Studies, 5( 2), 145-156.

Rywkin, M. (2010). The Geopolitics of the Caspian Sea Basin. American Foreign Policy Interests, 32(2), 93-102.

Su, C., Qin, M., Tao, R., \& Moldovan, N. (2019). Is Oil Political? From the Perspective of Geopolitical Risk, Defence and Peace Economics, DOI: 10.1080/10242694.2019.1708562 
Tsantoulis, Y. (2009). Geopolitics, (sub)regionalism, discourse and a troubled 'power triangle' in the Black Sea. Southeast European and Black Sea Studies, 9(3), 243258.

United Nation Conference On Trade And development (UNCTAD). (2020). Retrieved February 2, 2020 from: https://unctadstat.unctad.org/wds/TableVie wer/dimView.aspx

United Nations Statistics Division (2020). Retrieved January 2, 2020 from: https://unstats.un.org/unsd/snaama/country profile

World Bank (2020b). Iran Islamic Republic, Retrieved April 20, 2020 from: http://pubdocs.worldbank.org/en/94626155 4825524131/mpo-irn.pdf

World Bank. (2020a). "Fighting COVID-19" Europe and Central Asia Economic Update (Spring), Washington, DC: World Bank. Doi: 10.1596/978-1-4648-1564-5.

Zakharov, N. (2020). Asymmetric oil price shocks, tax revenues, and the resource curse. Economics Letters, 186, 108515.

\section{ABOUT THE AUTHORS}

Tahira Yasmin, email: tahira.yasmin@aau.ac.ae

Dr. Tahira Yasmin is an Assistant Professor in Business Administration Department at the Al Ain University, Al Ain, UAE.

Dr. Ghaleb A. El Refae is the President at the Al Ain University, Al Ain, UAE.

Dr. Shorouq Eletter is an Associate Professor in Business Administration Department at the Al Ain University, Al Ain, UAE. 